\title{
The Combined Effects of Service Offering and Service Employees on the Perceived Corporate Reputation
}

\author{
By Nha Nguyen* \\ Gaston LeBlanc*
}

\begin{abstract}
The present study contributes to the understanding of the role of two major components of the service production and delivery system in reinforcing the perceived corporate reputation. Specifically, the purpose of this study is to assess the combined effects of service offering and service employees on customers' perception of corporate reputation. A hierarchical multiple regression with interaction analysis was performed on data collected from customers of a banking institution to assess the main effect of service offering and service employees, as well as their interactive effect on customers' perception of corporate reputation. A significant interaction between service offering and service employees in their influence on corporate reputation was found. This results suggest that service employees intervene as a moderator variable in the relationship between service offering and corporate reputation. Furthermore, service organizations should focus on the crucial role of the service offering during the service encounter and recognize the importance of service employees in such way to reinforce customers' perception of corporate reputation. The study has limited generalization given the convenience sample and the great variety of service industries. The efficacy of the direct measures and the hierarchical multiple regression must be considered. It would be helpful to realize similar studies in other service settings and to explore the exact nature of the interaction between service offering and service employees.
\end{abstract}

Keywords: Service offering, service employees, corporate reputation

\section{Introduction}

Corporate reputation, as a social identity, is extensively used in an organization's positioning strategy because of its important influence on the consumer's choice of products and services (Brown, 1995; Bonaiuto et al., 2012; Ruiz et al., 2016; Worcester, 2009). Moreover, corporate reputation helps to attract potential investors and qualified employees (Dutton et al., 1994; Fombrun and Shanley, 1990) and contributes to develop and maintain customer loyalty (Chang, 2013; De Leaniz et al., 2016; Robertson, 1993). Ultimately, corporate reputation has a significant impact on an organization's competiveness in the market place (Barnett et al., 2000; McMillan and Joshi, 1997) as well as its financial performance (Lee and Roh, 2012; Roberts and Dowling, 2002).

\footnotetext{
* Professor of Production and Operations Management, Faculty of Business Administration, University of Moncton, Canada.

* Professor of Marketing, Faculty of Business Administration, University of Moncton, Canada.
} 
In the context of service management, the service production and delivery system is considered as a pivot in an organization' efforts to maintain and strengthen its reputation. From a marketing relationship perspective, the service offering and service employees, two major components of this system, should be given priority in the strategy of strengthening corporate reputation (Zeithaml et al., 2013). For example, the performance of service employees helps to attract target groups and define corporate reputation (Cravens and Oliver, 2006; Helm, 2011; Nguyen, 2010). Moreover, the provision of services of high quality strengthens corporate reputation (Wang et al., 2003; Worcester, 2009).

In most previous research, the individual and interactive effects of service offering and service employees on customers' perception of corporate reputation have not been extensively addressed (Men and Stacks, 2013; Worcester, 2009). In this study, in a service setting, we investigate the contribution of service employees in enhancing the effect of service offering on customers' perception of corporate reputation. Since service offering and service employees form an integral part of the service production and delivery system, they should act upon the customer's perception in a complementary manner (Lovelock and Wirtz, 2011; Zeithaml et al., 2013).

The results of this study should contribute to a greater understanding of the antecedents of the customer's perception of corporate reputation and, from a managerial perspective, assist in the management of service organizations in the formulation of strategies based on a judicious use of service offering and human resources to satisfy the customer' needs and expectations during the service encounter in order to reinforce corporate reputation.

The study consists of four parts. We will present, in the first instance, an overview of corporate reputation, service offering and service employees. The approach taken in this study is to measure corporate reputation from the customers' perspective along with their evaluation of the service offering on key service attributes. Moreover, service employees are assessed on the basis of performance attributes. Therefore, our objective is not to develop measurement scales for these constructs but to examine the impact of customers' assessments of the service offer and service employee performance on perceptions of reputation. Secondly, the model and the methods used to investigate the relationships between these concepts will be described and explained. Thirdly, the results of the investigation are presented and analyzed. Finally, a discussion of the managerial implications concerning service offering and service employees to enhance the customer's perception of corporate reputation, and future researches will be provided.

\section{Literature Review}

\section{Corporate Reputation}

The concept of corporate reputation has been studied mostly by researchers in the field of economics, organizational theory and marketing. In economics, 
reputation is related to a product's price and quality (Shapiro, 1983; Wilson, 1985). Researchers in organizational theory analyse reputation from the point of view of social identity (Men and Stacks, 2013). They describe it as an important and intangible resource that has a very significant impact on an organization's performance, and even on its survival (Fombrun and Shanley, 1990; Rao, 1994). Authors in marketing examine reputation under the rubric of brand equity (Aaker, 1996; Balmer and Greyser, 2006; Hur et al., 2014) and associate it with the organization's credibility (Herbig et al., 1994).

For certain authors, corporate reputation is defined as "the estimation of the consistency over time of an attribute of an entity" (Herbig and Milewicz, 1993, p. 18). For others, corporate reputation is viewed as "the subjective and collective opinion and assessment that stakeholders make of an organization" (van der Merwe and Puth, 2014, p. 147). Despite the use of various vocabularies and the difficulty of conceptualization, we observe that there is agreement on the essence of the notion of reputation. In fact, an organization's reputation is the direct result of its decisions and past actions. In this sense, corporate reputation may be viewed as a mirror of the organization's history and serves to communicate to target groups the information on the quality service offering and the performance of service employees in comparison with those of its competitors (Ruiz et al., 2016; Worcester, 2009; Yoon et al., 1993). Consequently, an organization can have several reputations, one for each attribute according to which it devises strategies (e.g., price, service quality, innovativeness and management quality). Each organization can also have a kind of overall reputation that represents its capacity to honour the promises it makes to its customers.

\section{Service Offering}

The service offering is a powerful means for the creation of sustainable value for customers (Chou et al., 2015, Petrick, 2002). It is composed of core and adjunct services. According to Eiglier and Langeard (1987), the core service is related to the principal reason why the customer chooses the service organization while adjunct services add value to the offering. The authors argue that when customers evaluate the service offering they use a globalization- simplification process, meaning that the overall performance of the offering can lead to satisfaction and a poor performance on one element of the offering can create dissatisfaction. In this light, the ability to offer a variety of competitive services and to deliver on the promises made to customers has a direct bearing on the service organization's reputation. When determining the mix of services to offer its customers, management must be innovative (Furrer et al., 2016) and ensure that services are offered in a convenient and timely manner (Berry et al., 2002). Waiting for service can have negative effects on customers' overall evaluation of the financial institution (Taylor, 1994), especially in situations where it is perceived as having control over the wait (Bitner, 1992). Indeed, access to service through effective procedure must reduce waiting time since "the wait is often treated as ancillary to the core service experience, when in fact it is the first interaction in the sequence of experiences that customers have 
with the firm" (McGuire et al., 2009, p. 270). Moreover, the service offering has the potential to improve an organization's competitive position and can lead to higher margins (Kamp and Parry, 2017). Finally, it is important to recognize that the service offering provides an opportunity to the service organization to engage with customers and participate in the co-creation of value (Grönroos and Gummerus, 2014). Therefore, the attributes related to the offer and service employees are key determinants of value creation during customer interactions with the service organization and significantly contribute to the fulfillment of the promises it makes to customers. In turn, this contributes to the building of a strong reputation. Therefore, the first hypothesis is stated as follows:

$H_{1}$ : The more positive the customer's assessment is of the provision of service, the greater is his/her perception of the organization's reputation.

\section{Service Employees}

The important role of service employees in the service production and delivery system has been acknowledged in the literature (Tombs and Rao Hill, 2014; Zeithaml et al., 2013). Indeed, the actions of service employees affect greatly customers' perception (Wu et al., 2015). In general, their role is twofold: gathering information and serving customers (Aldrich and Herker, 1979). Because of their strategic position, service employees receive from customers different kinds of information, mostly related to the service offering and delivery procedures. These types of information may be helpful to management while they attempt to improve service quality. The direct contact with customers and the knowledge they have about the service production and delivery system make service employees an important information source for the organisation. Moreover, they also have a marketing role as representatives of the organisation and influence its customer relations. Many service employees are considered as part-time marketers, because they "conduct marketing activities but do not belong to the marketing or sales department" (Gummesson, 1991, p. 60). They are hired and trained to meet the customer's expectations and to protect the organisation's interests.

The performance of service employees largely depends upon their ability to produce and deliver the service offering that satisfies the customers' needs and expectations (Zeithaml et al., 2013). A service organization wishing to reinforce its reputation must focus on enhancing their ability that relies mostly on their competence (Delcourt et al., 2013), often put into practice during the service encounter, or even their physical appearance (Söderlund and Rosengren, 2008; Tombs and Rao Hill, 2014). By doing this, the organization ensures that the customer has a positive perception towards its reputation. Hence the second hypothesis is as follows:

$\mathrm{H}_{2}$ : The more positive the customer's assessment is of the performance of service employees, the greater is his/her perception of the organization's reputation. 
Interactive Effect Service Offering-service Employees on Corporate Reputation

As mentioned earlier, a service is related to the primary reason why a customer chooses an organization in order to satisfy his primary needs. Generally speaking, the participation of service employees is required to carry out a transaction (Zeithaml et al., 2013). In the operation of a service production and delivery system, if service offering is viewed as a necessary condition, service employees should be considered as a sufficient condition in order to provide a service according to the customer's request. In this sense, they should act upon customers' attitudes and behaviors in a complementary manner (Zeithaml et al., 2013). Consequently, it is relevant to understand the nature of the interdependence between service offering and service employees.

Unlike previous studies that have examined separately the influence of service offering (Chou et al., 2015) and service employees (Dean and Rainnie, 2009; Wu et al., 2015) on customers' perception, in this study, these two components of the service production and delivery system are combined in assessing their effect on customers' perception of corporate reputation. In recognizing this interactive effect, we might expect that the appreciation of service offering can be enhanced if service employees are well trained to meet customers' specific needs during the service encounter. According to this reasoning, we formulate the third hypothesis as follows:

$H_{3}$ : The customer's assessment of the performance of service employees will moderate the relationship between his/her assessment of the provision of service and his/her perception of reputation.

The links between service offering, service employees and corporate reputation are graphically presented in Figure 1.

Figure 1. Relationship between Service offering, Service Employees and Corporate Reputation

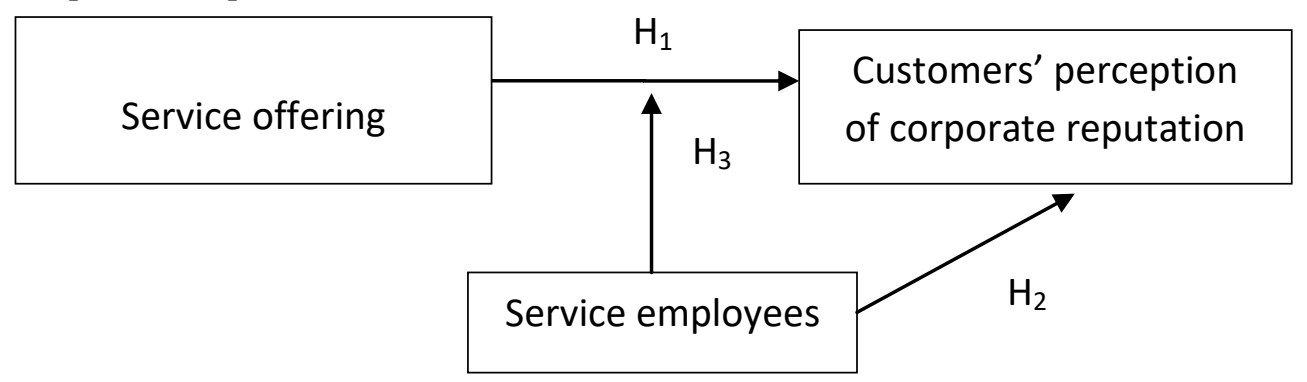

\section{Methodology}

Sample

A major financial institution located in Canada participated in this study. The literature review, along with a focus group interview held with eight 
customers of a bank at the Faculty of Business Administration of a University (Kennedy, 2002) and an interview with the Director provided the basis for the development of the questionnaire used in this study. A total of 1000 questionnaires were sent by mail to customers selected from the bank's list of customers. The questionnaires were accompanied by a cover letter from the Director requesting customer participation in the study. Respondents were asked to complete the questionnaire and return it in a self-addressed postage paid envelope within three weeks. No follow-up letters were sent. A total of 240 were returned within this time frame and used as a convenience sample.

\section{Analysis Procedure}

The assessment of the main influence of service offering and service employees, and their interactive effect on the customer's perception of corporate reputation will be conducted by the procedure proposed by Taylor (1997), based on the hierarchical multiple regression with interaction. This procedure seeks to detect the presence of potential higher order terms and, if need be, to include them in the regression model. Taylor $(1997$, p. 173) has underlined that "failing to capture true higher order and/or interaction effects can lead to problems associated with interpreting regression coefficients, particularly as importance weights." In the context of the current research, the regression model relating two independent variables to a dependent variable takes the form as follows:

REP $=\beta_{0}+\beta_{1}$ SO $+\beta_{2}$ SE $+\beta_{3}$ SO $*$ SE + POTENTIAL HIGHER ORDER TERMS $+\varepsilon \quad[1]$

Where:

REP $=$ Customer's perception of corporate reputation of the service organization

$\mathrm{SO}=$ Customer's perception of the service offering of the service organization

$\mathrm{SE}=$ Customer's perception of the performance of service employees of the service organization

SO*SE = Interaction between service offering and service employees

HIGHER ORDER TERMS: A set of higher order terms up to cubic form as well as other interaction effects.

\section{Measurement}

Let us remember that the primary objective of the present study is to examine the interdependence between service offering and service employees. To achieve this objective, we evaluate their main effect as well as their interactive influence on customers' perception of corporate reputation. To quantify these three constructs as presented in equation [1], we used direct measures based on global evaluations in the absence of a consensus on the valid scales. 
First, six items were used for the measurement of service offering: the variety of services offered, the services offered are competitive, the organization offers quality services, the waiting time for services is reasonable, the procedures for transaction are easy to follow and the price of services is competitive. These items support the literature and are deemed to be key determinants of value creation during customer interactions with the service provider (Berry et al., 2002; McGuire et al. 2009; Kamp and Parry, 2017). Second, five items were chosen to describe the ability of service employees: they are courteous and polite, they offer prompt service, they are willing to help customers, they seem well trained and they can be trusted. They are key dimensions associated with the performance of service employees (Zeithaml et al., 2013; Delcourt et al., 2013; Tombs and Rao Hill, 2014) and contribute to perceptions of the quality of services (Parasuraman, Berry and Zeithaml, 1991). Finally, four items were used to assess customers' perception of corporate reputation. The item the organization's mission is focused on meeting customers' needs is linked to the Customer Orientation Factor identified by Swoboda et al. (2013) in their research on corporate reputation and store equity, while the item measuring the customers`impression that the organization can keep its promises is associated with the work done by Herbig et al. (1994) describing reputation as the credible actions of the organization. Finally, an item measured customers' overall evaluation of reputation. These items are linked to the stream of research examining the construct of corporate reputation. Since the constructs examined are multidimensional, the advantage of the approach taken in this study lies in the use of indexes formed from multiple items that are summed and averaged rather than a single-item measure (Taylor and Baker, 1994). All of the aforementioned constructs were measured with the use of a bipolar seven-point scale with the anchors of strongly disagree (1) and strongly agree (7). 
Table 1. Correlation Matrix of the items used in the Model

\begin{tabular}{|c|c|c|c|c|c|c|c|c|c|c|c|c|c|c|c|}
\hline Variables & SO1 & $\mathrm{SO} 2$ & $\mathrm{SO} 3$ & $\mathrm{SO} 4$ & SO5 & SO6 & SE1 & SE2 & SE3 & SE4 & SE5 & REP1 & REP2 & REP3 & REP4 \\
\hline $\mathrm{SO} 2$ & 0.576 & & & & & & & & & & & & & & \\
\hline $\mathrm{SO} 3$ & 0.669 & 0.751 & & & & & & & & & & & & & \\
\hline $\mathrm{SO} 4$ & 0.585 & 0.588 & 0.540 & & & & & & & & & & & & \\
\hline SO5 & 0.546 & 0.510 & 0.571 & 0.451 & & & & & & & & & & & \\
\hline SO6 & 0.589 & 0.726 & 0.668 & 0.536 & 0.546 & & & & & & & & & & \\
\hline SE1 & 0.489 & 0.402 & 0.494 & 0.460 & 0.310 & 0.382 & & & & & & & & & \\
\hline SE2 & 0.476 & 0.382 & 0.530 & 0.572 & 0.267 & 0.384 & 0.685 & & & & & & & & \\
\hline SE3 & 0.466 & 0.397 & 0.539 & 0.503 & 0.316 & 0.399 & 0.563 & 0.641 & & & & & & & \\
\hline SE4 & 0.455 & 0.397 & 0.552 & 0.414 & 0.331 & 0.366 & 0.567 & 0.603 & 0.772 & & & & & & \\
\hline SE5 & 0.572 & 0.591 & 0.628 & 0.554 & 0.477 & 0.610 & 0.619 & 0.679 & 0.612 & 0.596 & & & & & \\
\hline REP1 & 0.440 & 0.426 & 0.532 & 0.271 & 0.292 & 0.410 & 0.383 & 0.440 & 0.400 & 0.450 & 0.497 & & & & \\
\hline REP2 & 0.469 & 0.565 & 0.555 & 0.330 & 0.386 & 0.525 & 0.418 & 0.469 & 0.503 & 0.494 & 0.630 & 0.676 & & & \\
\hline REP3 & 0.448 & 0.558 & 0.540 & 0.468 & 0.356 & 0.561 & 0.459 & 0.542 & 0.552 & 0.558 & 0.575 & 0.662 & 0.653 & & \\
\hline REP4 & 0.481 & 0.490 & 0.518 & 0.365 & 0.293 & 0.499 & 0.441 & 0.550 & 0.520 & 0.553 & 0.692 & 0.629 & 0.579 & 0.614 & \\
\hline MEAN & 5.63 & 5.25 & 5.46 & 5.43 & 4.58 & 4.98 & 6.10 & 5.60 & 5.60 & 5.70 & 5.52 & 4.97 & 4.91 & 5.02 & 5.39 \\
\hline S.D. & 1.56 & 1.65 & 1.50 & 1.61 & 2.36 & 1.65 & 1.56 & 1.71 & 1.64 & 1.54 & 1.60 & 1.71 & 1.80 & 1.56 & 1.39 \\
\hline
\end{tabular}


Table 2. Coefficients of Spearman Correlation Inter Index-Item and Cronbach's Alpha Coefficients

\begin{tabular}{|c|c|c|c|}
\hline $\begin{array}{l}\text { Indexes } \\
\text { (Constructs) }\end{array}$ & Items & $\begin{array}{l}\text { Spearman } \\
\text { correlation }\end{array}$ & $\begin{array}{l}\text { Cronbach's } \\
\text { alpha }\end{array}$ \\
\hline \multirow[t]{6}{*}{$\begin{array}{l}\text { SO (Service } \\
\text { offering) }\end{array}$} & $\begin{array}{l}\text { SO1 (Variety of } \\
\text { services) }\end{array}$ & 0.689 & 0.805 \\
\hline & $\begin{array}{l}\text { SO2 (Services are } \\
\text { competitive) }\end{array}$ & 0.815 & \\
\hline & SO3 (Quality services) & 0.825 & \\
\hline & $\begin{array}{l}\text { SO4 (Reasonable } \\
\text { waiting time) }\end{array}$ & 0.569 & \\
\hline & $\begin{array}{l}\text { SO5 (Easy procedure } \\
\text { for transaction) }\end{array}$ & 0.718 & \\
\hline & $\begin{array}{l}\text { SO6 (Competitive } \\
\text { price) }\end{array}$ & 0.759 & \\
\hline \multirow[t]{5}{*}{$\begin{array}{l}\text { SE (Service } \\
\text { employees) }\end{array}$} & $\begin{array}{l}\text { SE1 (Courteous and } \\
\text { polite) }\end{array}$ & 0.748 & 0.915 \\
\hline & $\begin{array}{l}\text { SE2 (Promptness of } \\
\text { service) }\end{array}$ & 0.853 & \\
\hline & $\begin{array}{l}\text { SE3 (Willingness to } \\
\text { help) }\end{array}$ & 0.866 & \\
\hline & SE4 (Seem well trained) & 0.821 & \\
\hline & SE5 (Can be trusted) & 0.830 & \\
\hline \multirow[t]{4}{*}{$\begin{array}{l}\text { REP (Corporate } \\
\text { reputation) }\end{array}$} & $\begin{array}{l}\text { REP1(Mission focused } \\
\text { on customers' needs) }\end{array}$ & 0.806 & 0.820 \\
\hline & $\begin{array}{l}\text { REP2 (Impression that } \\
\text { the organization can } \\
\text { keep its promises) }\end{array}$ & 0.865 & \\
\hline & $\begin{array}{l}\text { REP3(Other customers } \\
\text { have good things to say } \\
\text { about the organization) }\end{array}$ & 0.846 & \\
\hline & $\begin{array}{l}\text { REP4(Overall } \\
\text { evaluation of corporate } \\
\text { reputation) }\end{array}$ & 0.756 & \\
\hline
\end{tabular}

The correlation matrix of these items, presented in Table 1, shows that the coefficients of Spearman's correlation between the measures within a specific construct (varying from 0.451 to 0.772 ) are generally higher than those between the measures from different constructs (varying from 0.267 to 0.692 ). The use of Spearman rank correlation is preferred to Pearson product-moment correlation since certain variables are not normally distributed. Furthermore, Table 2 shows high values of Spearman's correlation between each index and its items (between 0.689 and 0.866 ). The assessment of the discriminant validity of the two indexes for service offering (SO) and service employees (SE) used as independent variables in Equation [1] was conducted following the procedure proposed by Fornell and Larcker (1981) by comparing the values of average variance extracted (AVE) of these indexes to their squared correlation coefficient. The calculation of AVE was based on the loading coefficients of confirmatory factor analysis (6 measures for SO: $0.907,0.854,0.792,0.783,0.583$ and 0.470 , and 5 measures for SE: $0.891,0.872,0.863,0.851$ and 0.845$)$. The AVE values of the two indexes 
( 0.853 for SO and 0.976 for SE) were both greater than their squared correlation coefficient (0.562). With acceptable Cronbach's alpha values (between 0.805 and 0.915) and considering the exploratory nature of the present study (Nunnally, 1978), these results constitute a demonstration, although partial and limited, of the validity and the reliability of the used measures.

\section{Findings/Results}

Following the procedure suggested by Taylor (1997), the results of identifying the (linear or curvilinear) nature of the relationship between the dependent variable (corporate reputation) and two independent variables (service offering and service employees) are reported in Table 3.

As can be observed, the quadratic term associated only with service employees is statistically significant. In light of these results, the form of equation [1] connecting service offering and service employees with corporate reputation and subject to testing is expressed as follows:

$$
\mathrm{REP}=\beta_{0}+\beta_{1} \mathrm{SO}+\beta_{2} \mathrm{SE}+\beta_{3} \mathrm{SO} * \mathrm{SE}+\beta_{4} \mathrm{SE}^{2}+\beta_{5} \mathrm{SO} * \mathrm{SE}^{2}+\varepsilon \quad[2]
$$

The next step of the analysis procedure consists of estimating various regression models derived from equation [2] and evaluating the change in the coefficient of determination $\left(R^{2}\right)$ in a hierarchical manner conforming to the apparition order of the independent variables as specified. As the independent variables are closely related, the centered data have been used to attenuate the error caused by the potential problem of multicollinearity (Aiken and West, 1991; Cronbach, 1987). Table 4 presents the results of the hierarchical multiple regression analysis and the variance inflation factor (VIF) values estimated for various models.

These results reveal that the regression coefficients representing the main effect of service offering and service employees on the customer's perception of corporate reputation are statistically significant in the presence of the interaction term between service offering and service employees ( $\mathrm{SO} * \mathrm{SE}$ ). These results confirm the hypotheses $H_{1}$ and $H_{2}$. The effect of service offering on the perception of corporate reputation is more important than service employees (beta of $\mathrm{SO}=0.528$ compared to beta of $\mathrm{SE}=0.398$ in model 2 in Table 4). This result suggests, therefore, the crucial role of the service offering in efforts to influence the customer's perception of corporate reputation. The presence of the interaction term (SO*SE) means that the regression coefficients representing the main effect of the two variables, service offering and service employees, are the weighted average effect of each variable across all observed values of the other variable. For example, the regression coefficient of service offering (beta of SO $=0.528$ in model 2 in Table 4) indicates its effect on the perception of corporate reputation at the average level of the evaluation of service employees, calculated for all the customers of the sample. Let us underline the fact that this average level is equal to zero since the centered data were used in the estimation of the model. 
Table 3. Identification of the Nature of the Relationship between the perceived Corporate Reputation and each Independent Variable

\section{Model}

$\mathrm{REP}=0.681 \mathrm{SO}$

$\mathrm{REP}=0.704 \mathrm{SO}+0.042 \mathrm{SO}^{2}$

$\mathrm{REP}=0.679 \mathrm{SO}+0.082 \mathrm{SO}^{2}+0.063 \mathrm{SO}^{3}$

No significant cubic term $(\mathrm{p}=0.639)$

$\mathrm{REP}=0.671 \mathrm{SE}$

$\mathrm{REP}=0.869 \mathrm{SE}+0.256 \mathrm{SE}^{2}$

$\mathrm{REP}=0.841 \mathrm{SE}+0.494 \mathrm{SE}^{2}+0.265 \mathrm{SE}^{3}$

and no significant cubic terms $(\mathrm{p}=0.258)$

$$
\begin{array}{ccc}
\mathbf{R}^{\mathbf{2}} & \mathbf{p} & \\
0.464 & 0.000 & \mathrm{~F}(1,238)=206.349 \\
0.466 & 0.000 & \mathrm{~F}(2,237)=103.249 \\
0.466 & 0.000 & \mathrm{~F}(3,236)=68.680 \\
& & \\
0.451 & 0.000 & \mathrm{~F}(1,238)=195.266 \\
0.477 & 0.000 & \mathrm{~F}(2,237)=108.126 \\
0.480 & 0.000 & \mathrm{~F}(3,236)=72.599
\end{array}
$$

No significant quadratic term $(\mathrm{p}=0.461)$

No significant quadratic term $(p=0.426)$

Significant quadratic term $(\mathrm{p}=0.001)$

Significant quadratic term $(\mathrm{p}=0.027)$

Table 4. Estimates of various Regression Models from Equation [ 2 ]

\section{Estimated \\ Model}

1

2

\section{Variable}

SO

SE

SO

SE

$\mathrm{SO} * \mathrm{SE}$

$\mathrm{SO}$

3

SE

$\mathrm{SO}^{*} \mathrm{SE}$

$\mathrm{SO}^{2} \mathrm{SE}^{2}$

${ }^{\mathrm{a}} \Delta \mathrm{R}^{2}=0.022, \mathrm{~F}_{1,236}=11.49, \mathrm{p}=0.00082$

${ }^{\mathrm{b}} \Delta \mathrm{R}^{2}$ is not significant $(\mathrm{p}=0.124)$

Beta
0.408
0.369
0.528
0.398
0.225
0.365
0.518
0.145
0.315
0.218

Beta
0.408

0.369

0.528

0.225

0.365

0.518

0.315

0.218

t-value
6.122
5.534
6.590
6.092
3.535
4.927
6.930
0.980
2.093
1.263

p-value

0.000

0.000

0.000

0.000

0.001

0.000

0.000

0.328

0.037

0.208

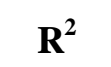

0.526

$0.548^{\mathrm{a}}$

$0.557^{\mathrm{b}}$

VIF
2.22
2.22
3.35
2.22
2.03
2.89
3.71
11.56
11.93
15.69

Tolerance

0.45

0.45

0.30

0.45

0.49

0.34

0.27

0.08

0.08

0.06 
Regarding the coefficient associated with the term SO*SE, it is statistically significant and confirms the hypothesis $H_{3}$, but with small magnitude (beta of SO $* S E=0.225$ in model 2 in Table 4). Because of the small magnitude and the exploratory nature of the study, this result should be interpreted with caution. Despite this remark, the significance of the interaction term found here is worth noting given the difficulty to detect statistically reliable interactions as suggested by numerous researchers in the field (Taylor and Baker, 1994). Consequently, we note that the presence of the interaction between service offering and service employees contributes to a better explanation of the customer's perception of corporate reputation.

The results show that the effect of service offering increases when service employees are stronger (beta of SO increases from 0.408 to 0.528 when beta of SE increases from 0.369 to 0.398 in the presence of SO*SE in model 2 in table 4). Consequently, it is relevant to suggest the moderator role of service employees in the relationship between service offering and corporate reputation. Since the coefficient of the term SO*SE is positive, this result can be interpreted as a congruence between perceptions of service offering and service employees. Statistically, the positive value of the coefficient associated with the term SO*SE indicates that the interactive effect increases (decreases) when the perception of service employees increases (decreases). This result demonstrates that service offering and service employees are an integral part of the service production and delivery system, and they must be jointly designed, developed and managed in linking with organizational values and strategy (Zeithaml et al., 2013).

Concerning superior order terms, the results in Table 4 show that only the coefficient associated with the quadratic term of service employees (coefficient beta of $\mathrm{SE}^{2}=0.315$ in model 3 in Table 4) is statistically significant. However, the term SO*SE becomes statistically not significant because of the severe multicollinearity problem, as shown by the values of the variance inflation factor (VIF) which are higher than the critical value that is 10 (Neter et al., 1983). Moreover, the results presented in Table 4 also reveal that the change in the coefficient of determination $\left(\Delta R^{2}\right)$ is statistically significant in the presence of the interaction term SO*SE only from model 1 to model 2 . Therefore, these results allow us to conclude that the model without higher order terms is appropriate.

\section{Discussion}

\section{Theoretical Implications}

From a conceptual perspective, the service offering is often the positioning statement of the organisation relative to the promises made to customers aimed at building corporate reputation and loyalty toward the organization over time. Therefore, the service production process must be managed to ensure that service employees have a good understanding of their role in the process and 
the script to follow when delivering quality service. Furthermore, the service organization, through its communications with its target markets, must educate customers as to the level of participation required of them to obtain a service. These actions should lead to customer satisfaction when both employees and customers read from a common script. Through the use of blueprints management must also analyze the complexity of the offer and set quality standards based on all the different moments of contact with the organization. Managing these moments of truth will lead to the co-creation of unique customer experiences (Patricio et al. 2008) and aid management in service innovation (Bitner et al., 2008). Most evidently, management must design the offer based on the expectations and needs of customers and through market research must continuously measure customer expectations to ensure that there is no gap between expectations of service and service delivery (Zeithaml et al. 1990). Managing the service offer over time will contribute to the building of a strong reputation.

Concerning service employees, the continuous improvement of their performance should be a guideline in human resources management and several actions could be considered, such as strengthening their ability to ensure the success of the transaction in accordance with customers' request. To strengthen this ability, first and foremost, management must develop an environment that facilitates individual learning (Oprime et al., 2012) with the purpose of encouraging the acquisition and sharing of information and knowledge related to the service production and delivery system. From this perspective, the upgrading of specific knowledge held by each service employee must be supported periodically by a training program against industry best-practice standards in order to enhance the customer's perception of the service organization's efforts to improve the quality.

With regard to the interactive effect service offering-service employees, the organization must build up its reputation based on the distinctive attributes of the service offering and a continuous renewal of knowledge helping to strengthen employees' ability on an ongoing basis. By emphasizing on service employees and combining it with the uniqueness of the service offering, the organization will maintain the outcome of its service production and delivery system up to customers' expectations and, consequently, their favorable perception about the organization's reputation.

\section{Practical Implications}

In addition to the above theoretical insights, this study also presents empirical evidence about the need for banking institutions to focus on both service offering and employees. Concerning the service offering, given the results of this study, the provision of high quality services must be a key objective of the financial institution and involve all members of the organization in developing standards and procedures leading to quality and customer satisfaction, this in in order to strengthen its reputation (Wang et al., 2003; Worcester, 2009). This focus on quality must be communicated to target groups in order to build the financial 
institution's positioning statement in the market (Ruiz et al., 2016). In doing so, management must be innovative and offer a variety of services aimed at better satisfying needs of its customers than competing offerings. Indeed, the service offer must be value driven in terms of efficient procedures to follow to obtain services, timeliness, and interest rates charged on loans and deposits. Furthermore, management must consider the service offering as an opportunity for service employees to engage with customers and participate in the co-creation of value (Grönroos and Gummerus, 2014), this as a means end to customer satisfaction and building reputation. Indeed, a good reputation in the market sphere will improve the financial institution's competitive position and profitability (Kamp and Parry, 2017).

Regarding service employees, it is imperative to invest in human resources in order to ensure a high quality service offering. For example, a banking institution should provide a continuing training program enabling employees, especially those who are in direct contact with customers, to renew their knowledge of financial services and strengthen their skills to provide good advices to customers.

\section{Conclusions}

The crucial role of service offering and service employees in the service production and delivery system, and the lack of empirical evidence to support the interdependence of their effect on customers' attitudes and behaviours were the prime motivation for the present study. Specifically within the banking setting, we examined the contribution of service employees as a moderator variable that strengthen the effect of service offering on customers' perception of corporate reputation. Since the exact nature of the interdependence between service offering and service employees is unspecified in the literature, this study reinforces the idea that service employees intervenes as a moderator variable on the relationship between service offering and corporate reputation.

In addition to the theoretical insights above, the present study also presents empirical evidence about the need for banking institutions to focus more in the training program established for service employees, knowing that their competence remains an essential component to ensure the success of the service production and delivery system and, consequently, enhance customers' perception of corporate reputation.

Regarding methodology, because of the multidimensional nature of the constructs involved in this study, it would be useful to examine their meaning, their formation and their aggregation in the mind of the consumers in order to obtain a better measure. It should be more efficient to investigate the relationship between service offering and service employees using valid scales of these constructs.

Several limits of the present study should be underlined. First of all, the exploratory nature of this study does not allow for the generalization of the findings to all types of service settings because of the great variety in service 
industries, especially since the data were collected from a convenience sample of consumers. Secondly, the efficacy of the direct measures used in the evaluation of the constructs must be considered (Peterson and Wilson, 1992). The selection of these measures was based on the meaning of each construct in the absence of measurement scales. Thirdly, the hierarchical multiple regression analysis method used here is not necessarily superior to other techniques to investigate potential higher-order and/or interactive effects (Jaccard et al., 1990; Taylor, 1997). For example, structural equation modelling with latent variables is a prominent alternative technique. However, this more complex method cannot examine the subtle distinction between closely linked constructs (Iacobucci et al., 1994). Finally, the weak variation of the coefficient of determination should invite us to interpret the results with caution.

\section{References}

Aaker DA (1996) Managing brand equity. New-York: The Free Press.

Aiken LS, West SG (1991) Multiple regression: testing and interpreting interactions age. Newbury Park CA : Sage.

Aldrich HE, Herker D (1979) Boundary-spanning roles and organisational structure. Academy of Management Review 2: 217-230.

Balmer JMT, Greyser SA (2006) Corporate marketing: integrating corporate identity, corporate branding, corporate communications, corporate image and corporate reputation. European Journal of Marketing 40:730-741.

Barnett ML, Boyle E, and Gardberg NA (2000) Towards one vision, one voice: a review essay of the $3^{\text {rd }}$ International Conference on corporate reputation, image and competitiveness. Corporate Reputation Review 3:101-111.

Berry L, Seiders K, and Grewal D (2002) Understanding service convenience. Journal of Marketing 66: 1-17.

Bitner MJ (1992) Servicescapes: the impact of physical surroundings on customers and employees. Journal of Marketing 56: 57-71.

Bitner MJ, Ostrom A, and Morgan F (2008) Service blueprinting: a practical technique for service innovation. California Management Review 50: 66-94.

Bonaiuto M, Caddeo P, Carrus G, De Dominicis S, Maroni B, and Bonnes M (2012) Food reputation impacts on consumer's food choice. Corporate Communications: An International Journal 17:462-482.

Brown SP (1995) The moderating effects of insuppliers/outsuppliers status on organizational buyer attitudes. Journal of the Academy of Marketing Science 23:170-181.

Chang KC (2013) How reputation creates loyalty in the restaurant sector. International Journal of Contemporary Hospitality Management 35: 536-557.

Chou CJ, Chen CW, and Conley C (2015) Creating sustainable value through service offerings. Research-Technology Management 58: 48-55.

Cravens KS, Oliver EG (2006) Employees: the key link to corporate reputation management. Business Horizons 49: 293-302.

Cronbach LJ (1987) Statistical tests for moderator variables: flaws in analyses recently proposed. Psychological Bulletin 102: 414-417.

Dean AM, Rainnie A (2009) Frontline employees' views on organizational factors that affect the delivery of service quality in call centers Journal of Services Marketing 
23: 326-337.

Delcourt C, Gremler DD, van Riel ACR, and van Birgelen M (2013) Effects of perceived employee emotional competence on customer satisfaction and loyalty. Journal of Service Management 24: 5-24.

De Leaniz PMG, Rodriguez DB, and Rodriguez I (2016) Corporate image and reputation as drivers of customer loyalty. Corporate Reputation Review 19: 166178.

Dutton JE, Dukerich JM, and Harquail CV (1994) Organizational images and members identification. Administrative Sciences Quarterly 39: 239-263.

Eiglier P, Langeard E (1987) Servuction, le marketing des services. Paris: McGrawHill.

Fombrun C, Shanley M (1990) What's in a name? Reputation building and corporate strategy. Academy of Management Journal 33: 233-248.

Fornell C, Larcker DF (1981) Evaluating structural equation models with unobservable variables and measurement error. Journal of Marketing Research 18: 39-50.

Furrer O, Sudharshan D, Tsiotsou RH and Liu BS (2016) A framework for innovative service design. The Service Industries Journal 36: 452-471.

Grönroos C, Gummerus J (2014) The Service revolution and its marketing implications: service logic vs service-dominant logic. Managing Service Quality: An International Journal 24: 206-229.

Gummesson E (1991) Marketing-orientation revisited: the crucial role of the part-time marketers. European Journal of Marketing 25: 60-75.

Helm S (2011) Employees' awareness of their impact on corporate reputation. Journal of Business Research 64: 657-669.

Herbig P, Milewicz J (1993) The relationship of reputation and credibility to brand success. Journal of Consumer Marketing 10: 18-24.

Herbig P, Milewicz J, and Golden J (1994) A model of reputation building and destruction. Journal of Business Research 31: 23-31.

Hur WM, Kim H and Woo J (2014) How CSR leads to corporate brand equity: mediating mechanisms of corporate brand credibility and reputation. Journal of Business Ethics 125: 75-86.

Iacobucci D, Grayson KA, and Ostrom A (1994) The calculus of service quality and customer satisfaction: theoretical and empirical differentiation and integration. In Swartz, T. A, Bowen, D.E. and Brown, S.W. Advances in services marketing and management. 3:1-67. Greenwich, CT: JAI Press.

Jaccard J, Turrisi R, and Wan CK (1990) Interaction effects in multiple regression. Sage University paper series on quantitative application in social sciences. 07072. Newbury Park CA: Sage.

Kamp B, Parry G (2017) Servitization and advanced business services as levers for competitiveness. Industrial Marketing Management 60: 11-16.

Kennedy S (2002) Using a focus group. ABA Bank Marketing 34: 32-34.

Lee J, Roh JJ (2012) Revisiting corporate reputation and firm performance link. Benchmarking: An International Journal 19: 649-664.

Lovelock C, Wirtz J (2011) Services marketing, people, technology, strategy. Essex: Pearson.

McGuire K, Kime S, Pullman LM and Russell L (2009) A framework for evaluating the customer wait experience. Journal of Service Management 21: 269-290.

McMillan GS, Joshi MP (1997) Sustainable competitive advantage and firm performance: the role of intangible resources. Corporate Reputation Review 1: 81-85. 
Men LR, Stacks DW (2013) The impact of leadership style and employee empowerment on perceived organizational reputation. Journal of Communication Management 17: 171-192.

Neter J, Wasserman W, and Kutner MH (1983) Applied Linear Regression Models. Homewood IL: Irwin.

Nguyen N (2010) Competence and benevolence of contact personnel in the perceived corporate reputation: an empirical study in financial services. Corporate Reputation Review 12: 345-356.

Nunnally J (1978) Psychometric Theory. New York: McGraw-Hill.

Oprime PC, de Sousa Mendes GH, and Pimenta ML (2012) Continuous improvement critical factors in Brazilian industrial companies. International Journal of Productivity and Performance Management 61: 69-92.

Parasuraman A, Berry L, and Zeithaml V (1991) Refinement and Reassessment of the SERVQUAL Scale. Journal of Retailing 67: 420-450.

Patrício L, Fisk R, and Cunha J (2008) Designing multi-interface service experiences: the service experience blueprint. Journal of Service Research10: 318-334.

Peterson RA, Wilson RW (1992) Measuring customer satisfaction: fact and artifact. Journal of the Academy of Marketing Science. 20: 61-71.

Petrick J F (2002) Development of a multi-dimensional scale for measuring the perceived value of a service. Journal of Leisure Research 34:119-134.

Rao H (1994) The social construction of reputation: certification contests, legitimation, and the survival of organizations in the American automobile industry: 18951912. Strategic Management Journal 15: 29-44.

Roberts PW, Dowling GR (2002) Corporate reputation and sustained superior financial performance. Strategic Management Journal 23:1141-1152.

Robertson TS (1993) How to reduce market penetration cycle times. Sloan Management Review 35: 87-96.

Ruiz B, Garcia JA, and Revilla A J (2016) Antecedents and consequences of bank reputation: a comparison of the United Kingdom and Spain. International Marketing Review 33: 781-805.

Shapiro C (1983) Premiums for high quality products as returns to reputations. Quarterly Journal of Economics 98: 659-679.

Söderlund M, Rosengren S (2008) Revisiting the smiling service worker and customer satisfaction. International Journal of Service Industry Management 19: 552-574.

Swoboda B, Berg B, and Schramm-Klein H (2013) Reciprocal Effects of the Corporate Reputation and Store Equity of Retailers. Journal of Retailing 89: 447-459.

Taylor S (1994) Waiting for service: the relationship between delays and evaluations of service. Journal of Marketing 58: 56-69.

Taylor SA (1997) Assessing regression-based importance weights for quality perceptions and satisfaction judgments in the presence of higher order and/or interaction effects. Journal of Retailing 73:135-159.

Taylor SA, Baker TL (1994) An assessment of the relationship between service quality and customer satisfaction in the formation of consumers' purchase intentions. Journal of Retailing 72: 163-178.

Tombs A, Rao Hill S (2014) The effect of service employees' accent on customer reactions. European Journal of Marketing 48: 2051-2070.

van der Merwe A WAJ, Puth, G (2014) Towards a conceptual model of the relationship between corporate trust and corporate reputation. Corporate Reputation Review 17: $138-156$. 
Vol. 4, No. $2 \quad$ Nha et al.: The Combined Effects of Service Offering and Service ...

Walsh G. Beatty SE (2007) Customer-based corporate reputation of a service firm: scale development and validation. Journal of the Academy of Marketing Science 35: 127-143.

Wang Y Lo H-P, Hui YV (2003) The antecedents of service quality and product quality and their influences on bank reputation: evidence from the banking industry in China. Managing Service Quality 13: 72-83.

Wilson HW (1985) Reputations in games and markets. In A.E. Roth (Ed.), GameTheoretic Models of Bargaining. 65-84. New York: Cambridge University Press.

Worcester R (2009) Reflections on corporate reputations. Management Decision 47: 573-589.

Wu YC, Tsai CS, Hsiung HW, and Chen KY (2015) Linkage between frontline employee service competence scale and customer perceptions of service quality. Journal of Services Marketing 29: 224-234.

Yoon E, Guffey HG, and Kijewski V (1993) The effects of information and company reputation on intentions to buy a business service. Journal of Business Research 27: 215-228.

Zeithaml VA, Bitner M.J., and Gremler DD (2013) Services marketing. New York: McGraw-Hill.

Zeithaml V, Parasuraman A, and Berry G (1990) Delivering service quality. New York: The Free Press. 